\title{
Paternalistic Leadership as a Reflection of Collectivism Culture
}

\author{
Ngurah Ayu Dian Anggraeni ${ }^{\# 1}$, Fuad Mas'Ud ${ }^{\# 2}$, Endah Winarti ${ }^{* 3}$

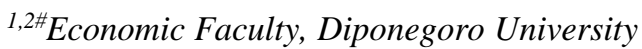 \\ Erlangga Tengah No.17, Indonesia \\ ${ }^{1}$ gurahayudian@gmail.com \\ ${ }^{2}$ drfuad0 62.gmail.com \\ 3*STIE Dharma Putra \\ Pamularsih Raya No.16, Indonesia \\ 3endahwinarti@gmail.com
}

\begin{abstract}
This research tries to complete transformational leadership and transactional leadership that is still controversial in some organizations. Therefore, paternalistic leadership becomes a model of leadership that is able to mediate the difference. In addition, to prove whether paternalistic leadership is still considered relevant in Indonesian environment to resolve different personalities. Paternalistic leadership is a consists of three leadership styles: authoritarian leadership, benevolent leadership, and moral leadership. The population in this study were all of the police officer at the Police Academy which amounted to 534 police officer. Samples taken using purposive judgment sampling method amounted to 179 police officer. Analytical techniques using AMOS 20.00 program. The result of research shows that collectivism culture has a positive influence on paternalistic leadership, collectivism culture can enhance paternalistic leadership. Paternalistic leadership has a positive influence on police officer engagement, paternalistic leadership can increase police officer engagement. Police officer engagement positively influence on police officer performance, police officer engagement can improve police officer performance. However, paternalistic leadership has no effect on police officer performance directly. Paternalistic leadership can enhance police officer performance through police officer engagement.
\end{abstract}

Keywords - Collectivism Culture, Paternalistic Leadership, Police Officer Engagement, Police Officer Performance

\section{INTRODUCTION}

Indonesia has a high culture of collectivism. The largest ethnic group in Indonesia is Javanese. Bapakism in Javanese culture is rooted in paternalism and high levels of power and authority. Indonesians are still influenced by their concern for the idea of bapakism that does not allow them to behave aggressively. This is similar to authoritarian leadership in Chinese culture. Andhap ashor shows the attitude of always respecting father figure such as teacher, manager, or boss. Subordinates recognize the rank of the boss. This is similar to moral leadership in Chinese culture. To be respected by others, Javanese must show outward behavior (such as dressing and finishing) and inner behavior (such as how to communicate and nrimo at work). This is similar to the benevolent leadership of Chinese culture. Based on this explanation, Javanese culture can adopt Chinese leadership style [8], [21]. This study explains paternalistic leadership as a reflection of collectivism culture. Paternalistic leadership can enhance employee engagement because paternalistic leadership has an attitude that encourages self-reliance.

The police academy is an educational institution to produce police officers. The history of the Police Academy has undergone various organizational and domicile changes until finally settling in Semarang. Based on Presidential Skep. 253/1959, the Police of the Republic of Indonesia changed to the Indonesian Police Force, thus the State Police School in Sukabumi which was a sponsorship of the Police Inspector School in Bukit Tinggi and Jogjakarta turned into the School of Police Force. Based on Kapolri No. Skep / 389 / IV / 1999, Police Academy declared separately from AKMIL, AAL, AAU. The purpose of the establishment of Police Academy is to be able to carry out police tasks with a noble personality and a strong mental, capable of performing police duties in maintaining security and public order as well as enforce the law, and able to carry out police duties in organizing and controlling public security disturbances. To achieve this, the Police Academy requires leaders who can protect, uphold justice, become leaders in solving 
problems, and become smart intellectually and emotionally.

When management practices are preceived as weak due to incorrect leadership, action is needed to impede the culture of KKN [5], [22], the frustration of colonialism [41], the loss of empathy towards others [4], and acceptance of a western context that is only on the surface [7]. To impede misleading management practices, it is necessary to apply appropriate leadership to the organization.

This research continues the previous research [23] which still requires similar research (police) in other countries then modified by research [22] which is considered relevant in Indonesia (paternalistic leadership) to solve research [39] on leadership behaviors that can be used to handle different personalities. Based on the Hofstede cultural framework, Javanese cultural characteristics were added to emphasize differences in Western leadership styles with Indonesia that were assumed to have no significant differences or were not reflected in organizational rules [21], [29]. When organizations use appropriate leadership styles then performance can be achieved [35], [42].

This research has a purpose to expand the theory so that the organization does not equate the understanding with the western cultural [12], [16]. Using the Chinese leadership style, we generalize the research question as follows:

RQ1 = In the context of Indonesia, how is the management of paternalistic leadership based on collectivism culture?

\section{LITERATUE REVIEW}

\section{A. Theoretical Foundation}

Leadership studies introduced in the 19th century have become increasingly controversial in the 20th century to the present. Transformational leadership is more dominant than transactional leadership. The presence of charismatic leadership derived from transformational leadership to break transactional leadership. Transformational leadership as a leadership model that is conceptualized and perfected in the context of western culture. If Indonesia wants to implement transformational leadership, it is necessary to combine it with other arrangements [7]. Transformational leadership is believed to be able to bridge the relationship of others [18]. However, transformational leadership has not been able to cultivate coaching and mentoring in subordinates [11] and transformational leadership have weak practices in taking a smoother approach to understanding the organization resulting in discomfort [2], [40].

Using the Weberian concept, charismatic leadership is still difficult to conclude concretely and has limited phenomena, so the dark side of charisma tries to divert managerial behavior such as consideration, duty, and participation with the assumption that charismatic leaders are hard to replace. Charisma is something that is not eternal in the organization and unpredictable [3], [10], [20]. Charismatic leaders will not exist unless the community is in a chaotic situation. Charismatic leaders tend to be sensitive to subordinate emotions, so to achieve the desired goals sometimes act unfounded on the deal and even against the norm. An inconsistent charismatic leader raises the negative side of emphasizing self-service rather than group, selfish, even deceiving to control followers [27].

Negative side that can still arise with charismatic leadership, led us to adopt the paternalistic leadership commonly applied to Chinese culture. Paternalistic leadership is a consist of three leadership styles such as authoritarian leadership (the Indonesian term Bapakism), benevolent leadership (Indonesian term Tepo Seliro), moral leadership (Indonesian term Andhap Ashor) [8], [12]. Paternalistic leadership is the relationship of a leader with a subordinate who professionally resembles a parent by giving an example of moral action including when giving punishment [30], [34].

Paternalistic leadership is a solution to a leadership style that can be exposed to different personalities [39]. Such as authoritarian leadership consists of authoritative (focus on independence) and authority (charismatic). Benevolent leadership consists of task-oriented leadership and peopleoriented leadership. Moral leadership consists of leaders who are incorruption, impartial, and magnanimity. In addition, paternalistic leadership is preferred over than transformational leadership [9]. 
B. Management of Paternalistic Leadership as a Reflection of Collectivism Culture

Leaders as moderator variables will succeed when they can recognize and understand cultural differences to avoid counterproductive and combine both dimensions of task and human relationships [13], [23]. Organizational culture and leadership style can complement the conceptual model of research [17].

This study was inspired by previous studies a few measurements of collectivism culture to distinguish the individualism culture [26], [28]. The reason is that the heterogeneity of organizational cultures [1] requires leaders who can play an effective role for all employees [25]. In addition, we find that it is possible that collectivist culture does not use transformational leadership. Examples found in Japan prefer transactional leadership [14].

Cultural heterogeneity can be controlled and managed, and this process is not relatively easy as it requires understanding. This is where the leader's role as a cultural architect in which leaders can keep subordinates obediently to the advice and recommendations of leaders, but on the other hand when there is no moral behavior, leadership can be derived performance [32].

To link culture with leadership, this study summarizes the cultural understanding of Hofstede (Collectivism), Trompenars (Family), and GLOBE (Institutional Collectivism, collectivism in groups). Leaders must be able to control the current culture as well as have a strong influence on the future of the organization. A leader will be a role model for subordinates when leaders use symbols as the main artefacts of organizational culture, empathetic, responsible, and award-winning [31]. Leaders need attention to how they remain in power both in task and human relationships [19].

Furthermore, leadership can affect police officer engagement. At the Police Academy, the term employee is called a police officer. The leadership role in employee engagement is still little done [6]. In addition, to examine employment engagement, previous researchers need to provide three leadership behaviors [33]. Employee engagement is a vast construction that touches almost all aspects of human resource management, so it's important to handle it appropriately. Successful leaders will be able to grow employee engagement to support performance [24].

\section{RESEARCH METHOD}

In determining the sample of a selected population, we reveal how and why the sample relates to the study, identifies the sample technique, uses techniques appropriate for the study, gives an assessment of the sample and gives a conclusion [15]. The study was conducted at the Police Academy. The research population is 534 . Sampling method is purposive sampling using Priority Scale List (DSP) data for 249 participants. Questionnaire survey was conducted. Seven questionnaire questions were discarded because the participants gave only partial responses. Total participants who responded 179 participants.

The instrument used in this research as follows:

\section{Collectivism Culture[37]}

a. The relationship of superiors with subordinates that indicate the extent to which the boss as an example and the extent to which a formal relationship.

b. The relationship between individuals and groups that indicate the extent to which individuals have a shame culture and the extent to which individuals hide their feelings and emotions.

c. Decision making that indicates the extent to which individuals prioritize agreement and the extent to which individuals prioritize mutual interests.

d. Communication that indicates the extent to which individuals avoid the word "no" and the extent to which individuals use the greeting that determines the status.

e. A management system showing the extent to which management is undertaken by the group and the extent to which individual initiatives are given to the group. 
2. Paternalistic Leadership[21]

a. An authoritarian leadership that shows how far the leader represents authoritarianism and authority.

b. Benevolent leadership showing the extent to which leaders use task-oriented considerations and the extent to which leaders use people-oriented judgments.

c. Moral leadership showing the extent to which leaders are generous and the extent to which leaders are incorruption.

\section{Police Officer Engagement[36]}

a. Job engagement indicating the extent to which the work situation is considered important by the police officer, the extent to which police officer participate actively in the work, and the extent of self-concept in accordance with job performance.

b. Organizational engagement that shows how far police officer are engaged in what happens to the organization.

\section{Police Officer Performance}
a. Quality of work
b. Quantity of work
c. On time
d. Independence of work
e. Work effectiveness

\section{IV.DISCUSSION}

\section{A. Instruments Analysis}

The results of the validity test show each of the indicators used to measure collectivism culture, paternalistic leadership, police officer engagement, police officer performance is valid with Cronbach alpha above 0,5. Reliability test results show all indicators of collectivism culture, paternalistic leadership, police officer engagement, police officer performance is consistent with Cronbach alpha above 0.7 .

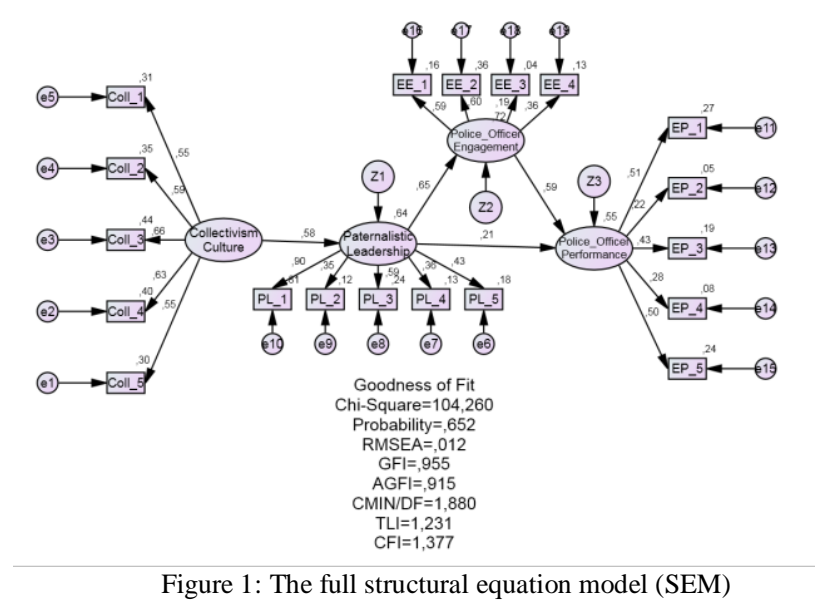

Based on the result of confirmatory factor analysis, Chi - Square value 104,260 with probability 0,652 ; GFI parameter value $=0.955$; RMSEA $=0.012 ;$ AGFI $=0.915 ; \mathrm{CMIN} / \mathrm{DF}=$ 1,$880 ; \mathrm{TLI}=1,231 ; \mathrm{CFI}=1.377$ so the model is acceptable.

Hypothesis 1: Culture Collectivism has a positive influence on paternalistic leadership.

The result of statistical test on hypothesis 1 shows the value of collectivism cultural with paternalistic leadership is $0.58>0.5$ that means $\mathrm{H} 1$ is accepted.

Hypothesis 2: Paternalistic leadership has a positive influence on police officer engagement.

The result of statistical test on hypothesis 2 shows the value of paternalistic leadership with police officer engagement is $0.65>0.5$ that means $\mathrm{H} 2$ is accepted.

Hypothesis 3: Police Officer Engagement has a positive influence on police officer performance.

The result of statistical test on hypothesis 3 shows the value of police officer engagement with police officer performance is $0.59>0.5$ that means $\mathrm{H} 3$ accepted.

Hypothesis 4: Paternalistic leadership has a positive influence on police officer performance.

The result of statistical test on hypothesis 4 shows the value of paternalistic leadership with police officer performance is $0,21<0,5$ means $\mathrm{H} 4$ is rejected.

\section{CONCLUSION}

Based on the analysis result, the research can be concluded. First, the results of hypothesis 1 testing show that collectivism culture has a positive 
influence on paternalistic leadership is proven, the better the collectivism culture the better the paternalistic leadership. Second, the results of hypothesis 2 testing show that paternalistic leadership has a positive influence on police officer engagement is proven, the better the paternalistic leadership the better the police officer engagement. Third, the result of hypothesis testing 3 shows that police officer engagement has a positive influence on police officer performance is proven, the better the police officer engagement the better the police officer performance. Fourth, the results of hypothesis 4 testing show that paternalistic leadership on the police officer performance is not proven.

\section{CONTRIBUTION OF RESEARCH}

Referring to the above research problem is "How is the management of paternalistic leadership based on collectivism culture?" The finding of this research that paternalistic leadership can be managed based on collectivism culture [12]. Cultural collectivism positively affects paternalistic leadership. This research has completed previous studies that require police research in other countries [38]. Finally, this research can complete research [39] which requires leadership for different personalities. Although paternalistic leadership has not been found to improve police officer performance directly. Paternalistic leadership can enhance police officer performance through police officer engagement.

\section{LIMITATIONS OF THE STUDY}

The limitations of this study are studies that rely on perceptual data, so the facts may differ from individual perceptions. The cultural environment of police academy to some extent tend to authorian rather than paternalistic. It is closely related to the objective of the academy that is to educate police officers who have high discipline.

\section{REFERENCE}

[1] Anderson, L. R. (1983). Management of the mixed-cultural work group Organizational Behavior and Human Performance, 31(3), 303-330.

[2] Bartram, T., \& Casimir, G. (2007). The relationship between leadership and follower in-role performance and satisfaction with the leader: the mediating effects of empowerment and trust in the leader. Leadership \& Organization Development Journal, 28(1), 4-19.
[3] Bryman, A. (1993). Charismatic leadership in business organizations: Some neglected issues. The Leadership Quarterly, 4(3-4), 289-304.

[4] Bubandt, N., \& Willerslev, R. (2015). The dark side of empathy: Mimesis, deception, and the magic of alterity. Comparative Studies in Society and History, 57(1), 5-34.

[5] Budiman, A. (2008). Post-colonial Indonesia: a study of the impact of the colonial legacy and foreign aid on Indonesian public sector institutions A case study in the Local/Provincial Government of West Kalimantan.

[6] Buenar Puplampu, B. (2010). Leadership as engagement, leadership as system development: A contextualised Ghanaian study. European Business Review, 22(6), 624-651.

[7] Bush, T. (2017). The enduring power of transformational leadership: SAGE Publications Sage UK: London, England.

[8] Cheng, B.-S., Boer, D., Chou, L.-F., Huang, M.-P., Yoneyama, S., Shim, D., . . . Tsai, C.-Y. (2014). Paternalistic leadership in four East Asian societies generalizability and cultural differences of the triad model. Journal of Cross-Cultural Psychology, 45(1), 82-90.

[9] Cheng, B. S., Chou, L. F., Wu, T. Y., Huang, M. P., \& Farh, J. L. (2004). Paternalistic leadership and subordinate responses: Establishing a leadership model in Chinese organizations. Asian Journal of Social Psychology, 7(1), 89-117.

[10] Conger, J. A., \& Kanungo, R. N. (1998). Charismatic leadership in organizations: Sage Publications.

[11] Craig, P. (2013). The relationship between leadership and employee job satisfaction in a military community. University of Phoenix.

[12] Den Hartog, D. N., \& Belschak, F. D. (2012). Work engagement and Machiavellianism in the ethical leadership process. Journal of Business Ethics, 107(1), 35-47.

[13] Enshassi, A., \& Burgess, R. (1991). Managerial effectiveness and the style of management in the Middle East: An empirical analysis. Construction Management and Economics, 9(1), 79-92.

[14] Fukushige, A., \& Spicer, D. P. (2007). Leadership preferences in Japan: An exploratory study. Leadership \& Organization Development Journal, 28(6), 508-530.

[15] Greener, S. (2008). Business research methods: BookBoon.

[16] Hale Öner, Z. (2012). Servant leadership and paternalistic leadership styles in the Turkish business context: a comparative empirical study. Leadership \& Organization Development Journal, 33(3), 300-316.

[17] Hartmann, F., Naranjo-Gil, D., \& Perego, P. (2010). The effects of leadership styles and use of performance measures on managerial work-related attitudes. European Accounting Review, 19(2), 275-310.

[18] Hautamäki, P. (2017). Business-to-Business Buyer-Seller Interactions: Personality and Transformational Leadership Theories' Perspective Leadership, Innovation and Entrepreneurship as Driving Forces of the Global Economy (pp. 531-542): Springer.

[19] Hogg, M. A. (2001). A social identity theory of leadership. Personality and social psychology review, 5(3), 184-200.

[20] House, R. J. (1976). A 1976 Theory of Charismatic Leadership. Working Paper Series 76-06.

[21] Irawanto, D. W. (2011). Exploring paternalistic leadership and its application to the Indonesian context: a dissertation presented in partial fulfilment of the requirement for the degree of Doctor of Philosophy in cross-cultural leadership at Massey University, Palmerston North, New Zealand. Massey University.

[22] Irawanto, D. W., Ramsey, P. L., \& Tweed, D. C. (2012). Exploring paternalistic leadership and its application to the Indonesian public sector. International Journal of Leadership in Public Services, 8(1), 420.

[23] Judge, T. A., Piccolo, R. F., \& Ilies, R. (2004). The forgotten ones? The validity of consideration and initiating structure in leadership research. Journal of applied psychology, 89(1), 36.

[24] Kompaso, S. M., \& Sridevi, M. S. (2010). Employee engagement: The key to improving performance. International Journal of Business and Management, 5(12), 89.

[25] Limsila, K., \& Ogunlana, S. O. (2008). Performance and leadership outcome correlates of leadership styles and subordinate commitment. Engineering, construction and architectural management, 15(2), 164 184.

[26] Lok, P., \& Crawford, J. (2004). The effect of organisational culture and leadership style on job satisfaction and organisational commitment: A cross-national comparison. Journal of management development, 23(4), 321-338. 
[27] Lussier, R. N., \& Achua, C. F. (2015). Leadership: Theory, application, \& skill development: Nelson Education.

[28] Markus, H. R., \& Kitayama, S. (1991). Culture and the self: Implications for cognition, emotion, and motivation. Psychological review, 98(2), 224.

[29] Moan, K., \& Hetland, H. (2012). Are leadership preferences universally endorsed or culturally contingent? Scandinavian Journal of Organizational Psychology, 4(2).

[30] Morris, H. (1981). A paternalistic theory of punishment. American Philosophical Quarterly, 18(4), 263-271.

[31] Nahavandi, A. (2016). The Art and Science of Leadership -Global Edition: Pearson.

[32] Naseer, S., Raja, U., Syed, F., Donia, M. B., \& Darr, W. (2016). Perils of being close to a bad leader in a bad environment: Exploring the combined effects of despotic leadership, leader member exchange, and perceived organizational politics on behaviors. The Leadership Quarterly, 27(1), 14-33.

[33] Nelson, S. A., \& Shraim, O. (2014). Leadership behaviour and employee engagement: a Kuwaiti services company. International Journal of Human Resources Development and Management, 14(1-3), 119-135.

[34] Ötken, A. B., \& Cenkci, T. (2012). The impact of paternalistic leadership on ethical climate: The moderating role of trust in leader. Journal of Business Ethics, 108(4), 525-536.

[35] Roberts, N. K., Williams, R. G., Schwind, C. J., Sutyak, J. A., McDowell, C., Griffen, D., . . Meier, A. H. (2014). The impact of brief team communication, leadership and team behavior training on ad hoc team performance in trauma care settings. The American Journal of Surgery, 207(2), 170-178.

[36] Saks, A. M. (2006). Antecedents and consequences of employee engagement. Journal of Managerial Psychology, 21(7), 600-619.

[37] Septarini, B. G., \& Yuwono, I. (2010). The Effect Of Collectivism Culture to Core Competency In Manager Lini Group PT Semen Gresik (PERSERO) TBK. Journal Unair.

[38] Tyagi, A., Dhar, R. L., \& Sharma, J. (2016). Police culture, tourists and destinations: A study of Uttarakhand, India. Tourism Management, 52, 563-573.

[39] Uusi-Kakkuri, P., \& Brandt, T. (2015). Preferred leadership behaviours by different personalities. International Journal of Business and Globalisation, 15(4), 461-474.

[40] Van Knippenberg, D., \& Sitkin, S. B. (2013). A critical assessment of charismatic-Transformational leadership research: Back to the drawing board? Academy of Management Annals, 7(1), 1-60.

[41] Vickers, A. (2013). A history of modern Indonesia: Cambridge University Press.

[42] Walumbwa, F. O., Mayer, D. M., Wang, P., Wang, H., Workman, K., \& Christensen, A. L. (2011). Linking ethical leadership to employee performance: The roles of leader-member exchange, self-efficacy, and organizational identification. Organizational behavior and human decision processes, 115(2), 204-213. 